\title{
Pombal and the Atlantic Empire: political impacts of the foundation of the Royal Treasury ${ }^{I}$
}

\author{
Miguel Dantas da Cruz[1]
}

\begin{abstract}
The Pombaline government has a fairly consensual meaning. It encompasses a period marked by the gradual concentration of deciding faculties in the monarch and the leading ministers and by the general introduction of legislation designed to exert higher control over the civil society. It was also a time of cultural change as far as the political models were concerned. The corporative nature of the regime was definitely suppressed. However, the consolidation of power of the Crown in the second half of the 18th century is frequently left to be analyzed. There is still much to be learned about the particularities involved in this transformation, namely in regard to governing routines or practices. This study reexamines and discusses the centralization of the Pombaline politics. The study is especially concerned with the predicaments and resistances encountered by the process initiated by Carvalho e Melo. In order to meet this ambition I will address the coexistence of the Royal Treasury (Erário Régio) with the Boards of Royal Finance (Juntas da Real Fazenda) of Brazil, which together formed a cornerstone of the political reform and a gateway to the all-powerful minister intentions.

Keywords: Royal Treasury; political centralization; Marquis of Pombal.
\end{abstract}

Pombal e o Império Atlântico: impactos políticos da criação do Erário Régio

\section{Resumo}

A governação pombalina encerra um significado bastante consensual. Trata-se de um período marcado pela gradual concentração defaculdades decisórias no monarca e no grupo dirigente e pela introdução generalizada de dispositivos legislativos destinados a controlar a sociedade civil. Trata-se também do momento em que a administração de cariz corporativo, vigente em todos os territórios da monarquia, foi definitivamente suprimida. No entanto, os termos da consolidação do poder da Coroa, na segunda metade dos Setecentos, ainda que elencados amiúde, ficam frequentemente por esmiuçar. É necessário compreender ainda muitas das nuances envolvidas nessa transformação, nomeadamente no que toca às rotinas de governo. Este estudo revisita e discute a centralização política pombalina. Procura, em especial, aferir os contornos e as resistências ao processo desencadeado por Carvalho e Melo no quadro da coabitação do Erário Régio com as Juntas da Real Fazenda do Brasil, que, em conjunto, formaram uma das estruturas político-administrativas que melhor encapsulavam as ambições do ministro de D. José I.

Palavras-chave: Erário Régio; centralização política; Marquês de Pombal.

Pombal y el Imperio Atlántico: impactos políticos de la creación de la Real Hacienda

\section{Resumen}

El gobierno de Pombal tiene un significado bastante consensual. Es un período caracterizado por la progresiva concentración de facultades decisorias en el monarca y el grupo en el poder y por la introducción generalizada de las disposiciones legislativas para controlar la sociedad civil. Este también es el momento en que la administración de carácter corporativo, en vigor en todos los territorios de la monarquía, fue eliminada definitivamente. Sin embargo, los términos de la consolidación del poder de la Corona en la segunda mitad del siglo 18, aunque muchas veces enumerados, con frecuencia quedan por escudriñar. Es necesario comprender aún muchos de los matices implicados en esta transformación, particularmente con respecto a las rutinas del gobierno. Este estudio revisa y discute la centralización política de Pombal. También busca, en particular, evaluar los contornos y las resistencias al proceso desencadenadas por Carvalho y Melo bajo la cohabitación de la Real Hacienda con las Juntas de Real Hacienda de Brasil, que juntas formaron una de las estructuras político-administrativas que mejor contenían la ambiciones del Ministro de D. José I. Palabras clave: Real Hacienda; centralización política; Marqués de Pombal.

Pombal et l'Empire Atlantique: répercussions politiques de la création du Trésor Royal

\section{Résumé}

Le gouvernement de Pombal a une signification consensuelle. C'était une période marquée par la concentration de décisions au monarque et son groupe dirigeant et par l'introduction de dispositifs législatifs pour contrôler la société civile. Il a été aussi le moment oú ladministration de caractere corporatif, en vigueur dans le territoire monarque, a été supprimée définitivement. Cependant, les termes de la consolidation du pouvoir de la couronne, dans la seconde moitié des 1700, même souvent énumérés, se sont avérés insuffisants. Il est nécessaire en effet de comprendre dês nombreuses nuances inhérentes à la transformation, principalement en ce qui concerne les routines du government. Cette étude revisite et discute la centralization politique de Pombal. On s'efforce de définir les formes et les résistances au processus lancé par Carvalho et Melo en concernant la cohabitation du Trésor Royal avec le quartier de la Real Fazenda au Brésil, qui ont formé une des structures politico-administrative qui correspondaient plus à les ambitions du ministre D. José I.

Mots-clés: Trésor Royal; centralisation politique; Marquès de Pombal.

Article received on September 16, 2014, and approved for publication on October 13, 2014.

[1] Institute of Social Sciences at University of Lisboa - Lisbon - Portugal. E-mail: miguel.cruz@ics.ulisboa.pt

\section{Translated by Andréa Brüning Beltrão.}

'The first version of this text was presented at the 31st APHES Conference - Economy and Institutions: Historical Perspectives, which took place on November 19 and 20, 2011, at the College of Economy of the University of Coimbra. I would like to thank Isabel Corrêa da Silva, Rita Carvalho, my ICS colleagues, Professor José Vicente Serrão, and the referees from Tempo for their critical reading of the initial version of this paper. I would also like to thank Professor Nuno Gonçalo Monteiro for his suggestions. 
$\mathrm{T}$ his study addresses the process of political centralization that was initiated in the Portuguese monarchy during the second half of the 18th century, a period marked by the gradual concentration of deciding capabilities in the monarch and in its leading ministers as well as by the widespread implementation of mechanisms designed to exert a high dominance of the civil society. Strongly committed to the discussion of a very controversial historiographic concept ${ }^{2}$ this study investigates the relationship between the Royal Treasury (Erário Régio) and the Boards of the Royal Treasury (Juntas da Real Fazenda) of Brazil, which together formed one of the political-administrative structures that best encapsulates the ambitions of Sebastião de Carvalho e Melo. ${ }^{3}$

The Pombal ministry constitutes an unavoidable subject in the Portuguese and international historiography. Moreover, similarly to what happens with other figures related to the enlightened despotism, there is a long tradition of work devoted to the main ruler of 18th century Portugal. There is also plenty of controversy. Its controversial inclusion into the enlightened reformism, ${ }^{4}$ in its multiple forms, ${ }^{5}$ the formal statute of its political position (Prime Minister without official nomination), and the guiding references of its political and economic action (of which he himself pointed out the names Sully and Richelieu) ${ }^{6}$ are all important historiographical research subjects.

Pombalism corresponded to a period of political transition of extreme importance, even when, in a parallel debate, preference is given to the historical preponderance of the Liberal Revolutions to the subsequent development of the State as we know it. ${ }^{7}$ It was a decisive turning point as far as the political

\footnotetext{
${ }^{2}$ The issue is not merely terminological, but we can say it is a formal one. Indeed, it is rare for someone to present themselves as having the objective of discussing the development of the centralization of politics per se, as authors like José Esteves Pereira have. However, many researches show that same concern. They simply do not express it in so many words. See José Esteves Pereira, "Teorização absolutista e centralização”, In: _. . Percursos de história das ideias, Lisboa, INCM, 2004, p. 107-123.

${ }^{3} T$ he diffusion of Boards of Finance was not particularly fast. The first one installed was in Goiás, in 1761, but the last few were only established during the second decade of the 19th century.

${ }^{4}$ The inclusion of Pombal in the Movement of Enlightenment has shown to be especially difficult. It is true that D. José I leading minister often legislated in accordance with the reformatory spirit of the second half of the 18th century, However, it is no less true that, at times, he adopted completely outdated practices that had been pushed aside by many European governments. These contradictions were specially well explained by Ana Cristina Araújo, A Cultura das Luzes em Portugal - temas e problemas, Lisboa, Livros Horizonte, 2003. For example, the affirmation of the Pombaline Cultural politics, based on the creation of the General Directory of Studies, the creation of the Royal Press, and the establishment of a National Plan of Education (among other initiatives), cohabited with the suppression of the newspaper press, which had a more literary and philosophical focus starting from 1740. In this regard, see also Kenneth Maxwell, "Pombal: the paradox of enlightenment and despotism”, In: Hamish M. Scott, Enlightenment Absolutism. Reform and reformers in later eighteenth-century Europe, Londres, MacMillan, 1990, p. 75-118; Nuno Gonçalo Monteiro, "Pombal's government: between seventeenth-century valido and Enlightenment", In: Gabriel B. Paquette (org.), Enlightened reform in Southern Europe and its Atlantic colonies, c.1750-1830, Farnham, Ashgate, 2009; José Luís Cardoso; Alexandre Mendes Cunha, "Discurso econômico e política colonial no Império Luso-Brasileiro (1750-1808)", Tempo, vol. 16, n. 31, 2011, p. 65-88.

${ }^{5}$ Studies done in the past few decades have redefined the conceptual map of Enlightenment. Today it is very clear that it can only be correctly interpreted in light of the political and geographic context. Among many other examples, see: Jonathan Israel, Radical Enlightenment: Philosophy and the making of Modernity, 16501750, Notre Dame, the University of Notre Dame Press, 2001; Gertrude Himmelfarb, The Roads to Modernity: the British, French and American Enlightenment, New York, Knopf, 2004; and Gabriel B. Paquette (org.), Enlightened reform in Southern Europe and its Atlantic colonies, c.1750-1830, Farnham, Ashgate, 2009. ${ }^{6}$ Nuno Gonçalo Monteiro, D. José - na sombra de Pombal, Lisboa, Temas e Debates, 2008, p. 293-304. ${ }^{7}$ For the Portuguese case, see, for example, Pedro Cardim, "Centralização política e Estado na recente historiografia sobre o Portugal do Antigo Regime", Nação e Defesa, n. 87, 1998, p. 129-158.
} 
government was concerned: the active administration overcame the traditional corporative way of government. ${ }^{8}$ From then on, politics was not just the exercise of judicative functions mainly oriented toward the ultimate goal of preserving the order of things. ${ }^{9}$ Remarkably, as José Vicente Serrão suggested, it was the traditional institutions - intrinsically opposed to political innovations - that assured the indispensable support to Carvalho e Melo's initiative. In his words, "Pombalism identifies itself with the State and uses it in its reformatory effort, which tries to encompass every domain of national life". ${ }^{10}$ It is not by chance that the idea of an Enlightenment with "State's features" remains seductive, ${ }^{11}$ at least among historians who feel more comfortable connecting Carvalho e Melo to that great European movement.

Nevertheless, it should be noted that if the Pombal reform seems evident by itself and, because of that, is accepted without much reluctance, its efficiency has been frequently left to be analyzed. The symptoms of the Crown's influence on multiple plans (judicial, legislative, fiscal, military, among others), in Carvalho e Melo's Portugal, seem to be so evident that their demonstration has apparently become superfluous. By articulating the vast legislative reform carried out by D. José I's main minister with the concentration of power in his hands, it is assumed (not without reason) that this conjuncture was marked by the irresistible progression of centralizing directives, emanated by a truly uncontested government. However, except for some notable exceptions, ${ }^{12}$ the process of political centralization, initiated by Pombal and, above all, the administrative resistance it faced (during and after his consulate), remain distant from the historiographic agenda, at least as a specific object.

We lack, for example, studies that closely follow the inner workings of some of the structures that were founded as a result of Carvalho e Melo's reformatory frenzy and that are frequently listed without additional research. In this regard, Damião Rodrigues, in a paper originally published in Tempo, underlined the need to analyze the "discrepancies between the intentions and the results" and "between the ambitions of the legislator and the limits of the implementation of the project".13

\footnotetext{
"José Subtil, "Os poderes do centro", In: António Hespanha (coord.), História de Portugal: o Antigo Regime, vol. 4, Lisboa, Estampa, 1998, p. 143.

${ }^{9}$ Michel Senellart, Les arts de gouverner. Du régime médiéval au concept de gouvernement, Paris, Seuil, 1995 ${ }^{10}$ José Vicente Serrão, "Sistema político e funcionamento institucional", In: Fernando Marques da Costa; Francisco Contente Domingues; Nuno Gonçalo Monteiro (orgs.), Do Antigo Regime ao Liberalismo, Lisboa Vega, 1989, p. 19.

"For this perspective, see Pedro Calafate, "Filosofia política", In: portuquês: as Luzes, vol. 3, Lisboa, Caminho, 2001, p. 45-62.

${ }^{12}$ Among others, see: Carla M.J. Anastasia, "Lei da Boa Razão e o novo repertório da ação coletiva nas Minas setecentistas", Varia Historia, n. 28, 2002, p. 29-38; Joaquim Romero de Magalhães, "Um novo método de governo: Francisco Xavier de Mendonça Furtado, Governador e Capitão-General do Grão-Pará e Maranhão (1751-1759)", Revista do Instituto Histórico e Geográfico Brasileiro, vol. 165, n. 424, 2004, p. 183-209; and José Damião Rodrigues, "'Para o Socego e tranquilidade publica das Ilhas': fundamentos, ambição e limites das reformas pombalinas nos Açores", In: __... Histórias atlânticas: os Açores na primeira modernidade, 2. ed. Lisboa, CHAM, 2012, p. 205-228.

13/bidem, p. 211.
} 
Many of the nuances involved in this transformation still need further research, namely in regard to those new inner workings of the government. For example, it needs to be known if Carvalho e Melo's measures channeled the resolution of all matters toward Lisbon, or if the expansion of governmental intervention was supplemented by a (probably indispensible) delegation of powers in the peripheral administration, particularly in colonial matters.

In this regard, a question arises, which is rarely framed and which is tied to the specific terms of administrative change: did the reformist impulse of Pombal fundamentally modify the relationship between Lisbon and the local powers in America, restricting its autonomy (which corresponds to the more traditional concept of centralization)? Or did this reformist impulse correspond to a process that should be considered, above all, at the level of royal administration, that is, in the context of the interaction between the central organs and the peripheral administration (and, in this case, it may be better to talk about bureaucratic decentralization, due to the possible reinforcement of attributions conceded to the periphery)?

Naturally, this city council autonomy did
not receive (most likely it never did) wide support and,
from 1711 on, began to be eradicated

This task - understanding what really changed with Pombal's political reform - is nonetheless notably difficult. It is particularly difficult to find a platform for historiographic dialogue. The political history of the Portuguese Empire, renewed by a more post-structuralist approach, rejected the idea of State, while at that same time discarding the idea of centralization, which is certainly a questionable move. At least, this is the interpretation of leading historians such as Laura de Mello e Souza, ${ }^{14}$ who remains especially wary about the applicability of this perspective to the 18th century Portuguese Empire, or Diogo Ramada Curto, who, in the footsteps of Christopher Bayly, underlined the convenience of restituting the "colonial State with all its limitations as an agent of history". ${ }^{15}$

Though not universally adopted, ${ }^{16}$ this methodological option has been transforming the administrative history of Portuguese America into the history of a permanent negotiation between the Colony and a remote Crown.

\footnotetext{
${ }^{14}$ Laura de Mello e Souza, O Sol e a Sombra: política e administração na América portuguesa do século XVIII, São Paulo, Companhia das Letras, 2006, p. 57.

${ }^{15}$ Diogo Ramada Curto, Cultura imperial e projetos coloniais (séculos XV a XVIII), Campinas, Editora da UNICAMP, 2009, p. 9, and Christopher Bayly, Origins of nationality in South Asia: patriotism and ethical government in the making of modern India, Nova Deli, Oxford University Press, 1998.

${ }^{16}$ There are various authors that reject the idea of a nearly acephalous monarchy, in which the crown represented just one more power. Among them, I would like to point out Fernanda Olival, "Mercês, serviços e circuitos documentais no Império Português", In: Maria Emília Madeira dos Santos; Manuel Lobato (orgs.), O domínio da distância - comunicação e cartografia, Lisboa, IICT, 2006, p. 59-71.
} 
The deliberate emphasis on the dynamics of continuity (particularly in regard to the social aspects of colonization) makes the great political and institutional transformations of the Empire or even the fractures inserted into the colonial policy (a concept that has almost disappeared from the historiographic lexicon) difficult to identify. It is no wonder glaring discrepancies can be detected in the assessments that authors of recognized authority make regarding the chronology and purposes of the Portuguese Atlantic policy. ${ }^{17}$

In this regard, the case of the Royal Treasury and the system of Boards of the Administration of the Royal Treasury ${ }^{18}$ which it overlooked are quite meaningful; being that they are completely submerged by a historiographical perspective committed to other priorities. In this sense, it is not surprising that we know so little about its inner workings and about the way these inner workings embodied a new imperial approach. Despite the contributions of authors such as Dauril Alden or Marcos Carneiro de Mendonça, ${ }^{19}$ the level of institutional and organizational dependency of the Boards of Finance is essentially ignored. Presumably, we assume that such subordination would be enormous, because this is more compatible with the reformist initiative of Carvalho e Melo. But, was this how it happened? Or are we being deceived by a "unilateral reading of Pombaline progress", to use José Esteves Pereira's words? ${ }^{20}$

In this text, it is precisely the political modifications introduced by Pombal in the Portuguese colonial administration that were examined, sounding the contradictions that emerged in the relationship between the Royal Treasury and the Rio de Janeiro Board of Finance. Two traditionally sensitive matters of the Ancien Régime governments received special attention: the control of the financial resources for war and the control of the tax-farming procedures. ${ }^{21}$

The text is divided into two parts. The first intends to synthetically highlight the political significance of the creation of the Royal Treasury, pointing out the way in which other councils and departments of the Kingdom were affected. The second part covers the way in which the jurisdiction of this new institution was extended to Portuguese America.

\footnotetext{
${ }^{17}$ Such divergences were, for example, noted by Nuno Gonçalo Monteiro, "As reformas na monarquia pluricontinental portuguesa: de Pombal a D. Rodrigo", In: João Fragoso; Maria de Fátima Gouvêa (orgs.), 0 Brasil colonial: 1720-1821, Rio de Janeiro, Civilização Brasileira, 2014, p. 112.

${ }^{18}$ Henceforth and to facilitate the discourse, the expression Board of Finance will be used.

${ }^{19}$ Dauril Alden, Royal government in Colonial Brazil, with special reference to the administration of the Marquis of Lavradio, Viceroy, 1769-77, Los Angeles, University of California Press, 1968, p. 279-352; Marcos Carneiro de Mendonça, O Erário Régio no Brasil, Rio de Janeiro, Ministério da Justiça, 1968. In this respect, see also the paper from Ângelo Alves Carrara, Receitas e despesas da Real Fazenda do Brasil - século XVIII, Juiz de Fora, Editora da UFJF, 2009.

${ }^{20}$ José Esteves Pereira, “Teorização absolutista e centralização", In: Lisboa, INCM, 2004, p. 121.

${ }^{21}$ In a certain sense, the advice of the previously referred José Damião Rodrigues is followed. For the Portuguese historian, the significance of the political and cultural changes of Pombalism could be collected in the administrative documentation and the correspondence between the center and the periphery, and not only in the writings of the mentors of the new regime. José Damião Rodrigues, "'Para o Socego e tranquilidade publica das Ilhas': fundamentos, ambição e limites das reformas pombalinas nos Açores”, In: __.. Histórias atlânticas: os Açores na primeira modernidade, 2. ed., Lisboa, CHAM, 2012, p. 208.
} 


\section{Before the Royal Treasury: some aspects of political-administrative dispersion}

The historiographical oblivion of the Royal Treasury is only matched by the attention it received from contemporary observers. Jacome Ratton, for example, noted that the Royal Treasury was "a monument that in and of itself was enough to eternalize the memory of this great Monarch [D. José I]" ${ }^{22}$ Despite our lack of knowledge, it is quite reasonable to defend the creation of the Royal Treasury as one of the main transformations introduced in the Portuguese political system in the second half of the 18th century.

According to the law of December 22, 1761, the Royal Treasury received the power to control all the revenues previously administered by the other political institutions. A general treasury was then established with the purpose of collecting those revenues, now notably termed as "public". The same treasury should similarly defray all expenses. ${ }^{23}$ It would have been difficult to find a more direct way to restrict traditional autonomies and jurisdictions. In fact, until then, other political institutions had the autonomy to administer revenues and rights that had been granted to them ${ }^{24} \mathrm{often}$ for the fulfillment of their functions or for the living expenses of their members (for example, the fees levied on the contracts). This certainly happened with the Overseas Council (Conselho Ultramarino). In 1670, in order to assure the regular dispatch of artillery and other war materials to the colonies, D. Pedro II consigned to the Council the fiscal surplus of the colonial administration. ${ }^{25}$

Usually, these revenues were collected by contractors, tenants, and other officials, and delivered to the stipulated agency. Subsequently, their accounts would be audited and checked in a specific department, although organically connected to the Finance Council (Conselho da Fazenda): the Bookkeeping House (Contos do Reino e Casa). Such was the procedure adopted for the kingdom and, since 1627 , for the overseas territories. ${ }^{26}$

There was also the tendency to delegate the administration of State revenues to institutions that were outside the direct control of the Crown. For example, in Brazil, up until the 1720s, various municipalities collected and administered taxes with the purpose of financing the military apparatus, sometimes without the intervention of the king's agent, the superintendent

\footnotetext{
22 Jacome Ratton, Recordações de Jacome Ratton sobre ocorrências do seu tempo em Portugal de maio de 1747 a setembro de 1810, 4. ed., Lisboa, Fenda, 2007, p. 226.

${ }^{23}$ José Roberto M. C. Coelho Sousa, Systema, ou Collecção dos Regimentos Reaes, tomo III, Lisboa, Oficina de Francisco Borges de Sousa, 1785, p. 451-473.

${ }^{24}$ Álvaro Ferreira da Silva, "Finanças Públicas", In: Pedro Lains; Alvaro Ferreira da Silva (orgs.), História económica de Portugal - 1700-2000: o século XVIII, vol. 1, Lisboa, ICS, 2005, p. 225.

${ }^{25}$ Miguel Dantas da Cruz, O Conselho Ultramarino e a administração militar do Brasil (da Restauração ao Pombalismo): política, finanças e burocracia, PhD thesis, Instituto Universitário de Lisboa, Lisboa, 2013, p. $151-158$

${ }^{26}$ Chapter XVIII of the regiment of the Houses of Bookkeeping revoked the practice of discharging in the colonies the officers who received revenues in those territories. From then on, everything needed to be confirmed in the kingdom (Regimento dos Contos, 1627). Cf. José Roberto M. C. Coelho Sousa, op cit., p. 367-446.
} 
(provedor). This means that, in Portuguese America, and contrary to what generally happened in the kingdom (with the exceptions of the cities of Porto and Setúbal), the municipalities exerted great influence over the armies, which sometimes were paid without the intervention of the king's officials. ${ }^{27}$ The period of war against the Dutch was especially illustrative of the role played by the city councils in this respect. ${ }^{28}$

Naturally, this city council autonomy did not receive (most likely it never did) wide support and, from 1711 on, began to be eliminated, first in Bahia and later in Pernambuco and then in Rio de Janeiro. ${ }^{29}$ It was not a colonial thing. Following the instability brought on by the War of the Spanish Succession, discussions about the role of the municipalities in fiscal matters also sprouted in the kingdom. The advice of the State Counselors reveals that times were in fact changing for the traditional autonomies of the câmaras municipais. ${ }^{30}$ Significantly, this political change started 40 years prior to the arrival of Pombal. Only with great difficulty would it be possible to place such responsibility in the hands of the all-powerful minister.

For the purpose of comparison, it should be noted that the same period witnessed, in British America, the reinforcement of the political military protagonism of the local powers (in this case, colonial assemblies), which took full advantage of the Franco-Spanish threats. ${ }^{31}$

Also regarding the administration of the fiscal revenues for Brazil's defense, it should be noted that the absence of a point of general coordination was the source of permanent conflict between the Overseas Council and the Finance Council (c.1705-1735). The revenues destined for the acquisition and transport of war materials to the Colony, administered by the Overseas Council, and the revenues destined to assure the purveyance of the Crown's ships, administrated by the Royal Warehouses in Lisbon (Repartição dos Armazéns), had a tendency to get mixed up, making the protection of Brazil an enormous challenge for the Portuguese institutional system.

Illustrative of the tension provoked by such difficulties was a consideration, made by the Warehouse Overseer (Marquis of Fronteira), demanding the preservation of good financial practices between the councils. D. Fernando de Mascarenhas highlighted that the Overseas Council should pay what it owed

\footnotetext{
${ }^{27}$ Biblioteca Nacional, Assentos da Câmara da Baía relativos aos fornecimentos das tropas de infantaria (julho de 1652), Documentos Históricos, vol. 79, Rio de Janeiro, 1948, p. 349-367.

${ }^{28}$ See, for example: Evaldo Cabral de Mello, Olinda Restaurada: guerra e açúcar no Nordeste, 1630-1654, 2. ed., Rio de Janeiro, Topbooks, 1998, and Wolfgang Lenk, Guerra e Pacto Colonial: exército, fiscalidade e administração colonial da Bahia (1624-1654), PhD thesis, Universidade Estadual de Campinas, Campinas, 2009.

${ }^{29}$ Miguel Dantas da Cruz, O Conselho Ultramarino e a administração militar do Brasil (da Restauração ao Pombalismo): política, finanças e burocracia, PhD thesis, Instituto Universitário de Lisboa, Lisboa, 2013, p. 158176. On this subject, see also Maria Fernanda Bicalho, "Inflexões da política imperial de D. João V", Anais de história de além-mar, n. 8, Lisboa, 2007, p. 37-67.

${ }^{30}$ Consulta do Conselho de Estado, de setembro de 1713. Academia das Ciências de Lisboa (ACL), Série Azul, n. 127, Papéis do Conselho de Estado, fls. 4-13v.

${ }^{31}$ lan Steele, "The anointed, the appointed, and the elected: governance of the British Empire, 1689-1784", In: P. J. Marshall (ed.), The Oxford history of British Empire: the eighteenth century, vol. 2, Oxford, Oxford University Press, 1998, p. 112.
} 
"because in this Kingdom it is inviolably observed the informal custom, which is almost a Law, that the debt contracted by one council should not be paid through the assets that another court administrates". ${ }^{32}$

By the same time, the same aristocrat went as far as proposing the incorporation of the Overseas Council (and of the Board of Commerce; Junta do Comércio) in the Royal Warehouses, which, in other words, implicated the suppression of the first. ${ }^{33}$ For Fronteira, the centralization of the colonial business in his department was the only institutional solution. At that moment, the plan for institutional convergence was rejected. Yet, its contemplation in the main circles of the monarchy, including in the considerations of the Duke of Cadaval, who considered it a product of unmeasured ambition of Fronteira, ${ }^{34}$ illustrates its viability.

This scenery of certain anarchy would suffer an important modification with the creation of the Royal Treasury, in 1761. Financially dependent on a new agency, the other departments and councils lost not only influence but also a reason for getting involved in disputes between themselves. In a certain sense, it is possible to say that Carvalho e Melo rearranged the Portuguese political system by excluding the other institutions from the administration of their consignments. Save for rare exceptions, ${ }^{35}$ which in fact were later corrected, the spectrum of the Portuguese institutions became implicitly subordinated to the Treasury and, consequently, to his inspector-general or to his presidents (from 1777 on). In reality, more than the local powers, the first victims of the Royal Treasury could very well have been the other central powers.

For the benefit of comparison, one cannot fail to stress the similarities between Carvalho e Melo and the British statesman Walpole, who, in Pombal's image, also never assumed the position of prime minister. Contrary to what Hamish Scott has argued, Walpole may not have been Carvalho e Melo's main

\footnotetext{
${ }^{32}$ Consideration made by the Marquis of Fronteira, probably from the period of the War of the Spanish Succession. Cf. Miguel Dantas da Cruz, O Conselho Ultramarino e a administração militar do Brasil (da Restauração ao Pombalismo): política, finanças e burocracia, PhD thesis, Instituto Universitário de Lisboa, Lisboa, 2013, p. 205.

${ }^{33} \mathrm{~A}$ proposal made by the Marquis of Fronteira, on October 24, 1712. Cf. Virgínia Rau; Maria Gomes da Silva, Os manuscritos do Arquivo da Casa do Cadaval respeitantes ao Brasil, vol. II, doc. 161, Coimbra, Imprensa da Universidade, 1956-1958, p. 108-110.

${ }^{34}$ Consideration made by the Duke of Cadaval regarding the proposition regarding the incorporating the Overseas Council and the Board of Commerce in the Warehouses, on November 28, 1712. Cf. Ibidem, doc. 164, p. 110-111.

${ }^{35}$ Most of the councils, like the Board of Three States, immediately became dependent on the Royal Treasury; others, however, kept some sort of autonomy that, in any case, did not last many years. This was the case of the administration of the House of Bragança (1765); of the House of Queens (1769); of the Bookkeeping of the Board of Conscience and Orders, Bookkeeping Offices of the Three Military Orders and of the General Treasury of the Captive (1774); of the $4 \%$ donation (administrated by the Board of Commerce until 1780); and of the Bookkeeping Office of the Literary Subsidy (1794). In the beginning of the 19th century, the "public" revenues not directly absorbed by the Royal Treasury were rare. Cf. Alzira Teixeira Leite Moreira, Inventário do Fundo Geral do Erário Régio, Lisboa, Tipografia Minerva do Comércio, 1977, p. xiv-xvi.
} 
reference. ${ }^{36}$ However, the fact that Pombal put himself as the head of the Royal Treasury, as general inspector, shows the British inspiration of his plan: Walpole also reinforced his political position by holding the post of First Lord of the Treasury, a post that would symptomatically be bound to the prime minister of Great Britain.

\section{The Royal Treasury and the political control of the overseas territories}

The constitution of a central point of collection of the royal revenues, exclusively administrated by the Royal Treasury, strongly limited other courts' capacities to act freely, making it impossible for them to pass payment orders. In practice, the Royal Treasury began to control the government when it assumed all the financial matters, which were formerly spread out.

\section{Carvalho e Melo streamlined the Portuguese political system as a whole when he excluded the administration of private consignments from it}

The administration of the colonies was no different. The councils and departments that in some form intervened in the administration of the colonial territories, particularly the Overseas Council, were now compelled to prepare the papers that should now mandatorily be sent to the Royal Treasury, for later expedition of the payment mandates. The only exception to this procedure was a letter signed by the "Royal Hand", which did not nullify the indispensable notification of the president of the Treasury. In the case of an emergency, related to "some expenses and payments in Brazil", the presidents of the different councils should personally deal with the president of the Treasury. The presidents of the Royal Treasury (and, before them, the general inspector) could, for their part, question the underlying reasons for those expenses and have them examined. They could ask for their legal support. Within these administrative solutions, there is an undeniable hint of modernity.

The issues that the law of December 22, 1761, left untouched, which would lead to the perpetuation of practices contrary to the spirit of that legislation, were corrected later. At that moment, the colonies were especially contemplated. The Overseas Council was then reminded of its limitations

\footnotetext{
${ }^{36}$ Hamish Scott, "The rise of the first minister in the eighteenth-century Europe", In: T.C. Blanning; David Cannadine (eds.), History and biography. Essays in hounour of Dereck Beales, Cambridge, Cambridge University Press, 1996, p. 21-52.
} 
regarding the authorization of expenditures. ${ }^{37}$ We should also underline, the failure of the subsequent objections made about this subordination to the Treasury. For example, in 1800 the Board of Marine Finance (Junta da Fazenda da Marinha), created specifically to deal with the provisioning and the construction of ships, was reminded it should follow the budget instructions given by the Treasury. ${ }^{38}$

The demotion of the Overseas Council certainly did not stop here. Although many papers related to payments, expenses and taxes were sent to the overseas councilors, they were mainly dispatched in the Treasury. Owing to this, many claims sent to the Overseas Council did not obtain the desired answer there. Such was the case of the frustrated representation of the aldermen of Sabará regarding the difficulties they faced to pay the wages of the majors nominated to train the militias (1777). ${ }^{39}$

For the same reason, it was also in the Treasury that administrative disputes between captaincies began to be settled, which were frequently related to the control of certain resources or to the desired right to auction contracts. For example, at the end of the 1760s, and after knowing that the contracts for the transit tolls (passagens) of Curitiba and Viamão had been auctioned by both São Paulo and Rio de Janeiro, the Rio de Janeiro Board received a warning that those contracts belonged to São Paulo. ${ }^{40}$ This order was reinforced by the Count of Oeiras himself, when he explicitly stated that "from now on, the Board of Finance should not auction contracts from the Brazilian government related to the districts of other General Captaincies and their subordinated Captaincies, but strictly the ones that encompassed the territory of that Captaincy".41

Among other central agencies, it was with the Secretaries of State that the Treasury found more obstacles in the pursuit of its political goals, particularly after the downfall of Pombal, who was simultaneously the Secretary of State and general inspector. At the outset, the spheres of intervention looked well defined, at least according to the interpretation of Carvalho e Melo. For example, in the beginning of the 1770s, the Marquis of Lavradio, Viceroy of Brazil, proposed a change in the procedures of the Board of Finance in Rio de Janeiro, advocating for more checking regularity. However, he did it via the Secretary of State, which could not have pleased D. José I's leading minister, always very cautious with bureaucracies. The Viceroy was then reminded of the correct bureaucratic channel for that proposal, which, nevertheless, was considered interesting by Pombal: "It is a very suitable the project for establishing a perpetual and unalterable method of governing the Superintendences (Provedorias) subordinated to that

\footnotetext{
${ }^{37}$ Decreto de 12 de junho de 1779. Cf. António Delgado da Silva, Collecção da Legislação Portugueza Suplemento à Legislação de 1763 a 1790, Lisboa, Typografia Maigrense, 1844, p. 471-473.

${ }^{38}$ Consulta da Junta da Fazenda da Marinha, de 22 de agosto de 1800. Biblioteca Central da Marinha - Arquivo Histórico (BCM-AH), Livro 2.384, fls. 212v-213.

${ }^{39}$ Representação dos oficiais da Câmara do Sabará. De 4 de agosto de 1777. Arquivo Histórico Ultramarino (AHU), Avulsos, Minas, cx. 111, doc. 47 (8.842).

40Provisão de 13 de julho de 1769. Tribunal de Contas (TC), Erário Régio (ER), n. 4.055, fl. 108.

${ }^{41}$ Carta do Conde de Oeiras de 29 de agosto de 1769. TC, ER, n. 4.055, fls. 115-116.
} 
Captaincy, which Your Excellency must send to the Royal Treasury, so that Your Majesty at the sight of it, may approve what he finds just". ${ }^{2}$

The conflicts of jurisdiction would be, however, more or less inevitable with an agency whose scope of intervention preceded the arrival of Carvalho e Melo. ${ }^{43}$ In this respect, the issue of Brazil's protection, due to the elements involved in it (political-military factor and a financial factor), would be particularly prone to causing misunderstandings. For example, when the Royal fleet arrived at Rio de Janeiro in 1791, the local Board of Finance shared with the Treasury that it could no longer afford to support the expenses incurred by the warships on its own (a problem that was far from being new ${ }^{44}$ ). They asked, then, to be freed from that duty, raising the possibility of those ships fulfilling their needs at other harbors along the Brazilian coast. In Lisbon, the Treasury, sensing the wider range of that problem, channeled the request to Secretary of State for the Navy, stressing, nevertheless, its perception to the queen D. Maria I:

Since the expenses with the aforementioned ships, the Board has declared, are customarily done by expedited orders in the respective conjunctures, those of which I consider to be emanated from the Secretary of State for the Navy, being certain, that by decree from June 12th, 1779 [which has already been mentioned] it became exclusive to the Court of this Royal Treasury the expedition of the Orders for any payment of the Royal Finance, although it is relative to those Domains; to obviate the inconsolable contradiction to the same orders, in which it should be expedited in consequence to this Expense; it seems that only His Majesty can determine what is more akin to his Royal Pleasure. ${ }^{45}$

The observations made by D. Fernando José de Portugal (penultimate Viceroy of Brazil) in Chapter 32 of the Regiment of Roque da Costa Barreto confirm the persistence of the difficulties associated with that situation. The future Marquis of Aguiar noted that in Rio de Janeiro, in the beginning of the 19th century, orders from the Secretary of State for the Navy were still received, and these ended up generating some sort of expenditure. And, contrary to what was prescribed in the law of December 22, 1761, many of these orders were not signed by the "Royal Hand". Still, he pointed out that all these orders were "noted" in the Rio de Janeiro Board of Finance, by which the president of the Treasury became informed. ${ }^{46}$

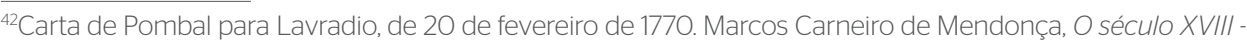
século pombalino do Brasil, Rio de Janeiro, Xerox, 1989, p. 513-514. Two years later, Lavradio’s proposal ended up being approved. Provisão de 18 de setembro de 1772. TC, ER, n. 4.055, fls. 164-165.

${ }^{43}$ André da Silva Costa, Os secretários e o Estado do rei: luta de corte e poder político (séculos XVI-XVII), Lisboa, Master's dissertation, Universidade Nova de Lisboa, Lisboa, 2008.

${ }^{44}$ Miguel Dantas da Cruz, O Conselho Ultramarino e a administração militar do Brasil (da Restauração ao Pombalismo): política, finanças e burocracia, PhD thesis, Instituto Universitário de Lisboa, Lisboa, 2013, p. 198-212.

${ }^{45}$ Exposição do Contador Geral, de 19 de novembro de 1791 (à margem: representação enviada a Martinho de Melo e Castro). TC, ER, n. 4.044, fls. 110-112.

${ }^{46}$ Regimento que trouxe Roque da Costa Barreto, mestre de campo general, em data de 23 de janeiro de 1677, com várias observações feitas pelo atual Vice-Rei... Biblioteca Nacional do Rio de Janeiro (BNRJ), 09, 02, 026, p. 45v-48v.
} 


\section{Structural dependencies: the organization of the system}

In the Empire, the Royal Treasury should act via the Boards of Finance system, which was established with more or less difficulty. In principle, it was a hierarchical relationship established within a framework of evident subordination which nevertheless is important to examine.

Each Board of Finance was integrated into the structure headed by the Royal Treasury, via a general bureau of audit (contadoria geral), which, in Lisbon, filtered a large portion of the communication with the monarch and with general inspector/president of the Treasury. All the members of the Board could engage in this communication. However, apparently only its presidents had direct access to the inspector general or the king. The remaining members of the Board had to write to the comptroller-general, in Lisbon. It is important to note that such a privilege did not exempt the correspondence of the president of the Boards from a thorough (many times, critical) examination by the comptroller-general, even when the letter arrived via the Secretaries of State.

The composition of the Boards varied from captaincy to captaincy, but it tended to incorporate traditional officials (as one can see in Figure 1), which was the case of the superintendent (provedor), who, nonetheless, lost much of his autonomy. Other officials were established and specifically sent to Brazil with the purpose of introducing the double-entry bookkeeping system. In this regard, two men (two clerks) are worth mentioning: João Correia Lemos, who remained in Rio de Janeiro until 1799, and Sebastião Francisco Betâmio, who built a truly Atlantic career, serving in Bahia, São Paulo, Rio Grande do Sul, and Angola.

Apart from the functional subordination inscribed into the initial constitution, which, for example, denied the Boards the use of contentious jurisdiction, ${ }^{47}$ there are signs that Lisbon had attempted to control them at other levels. Illustrative of this ambition was probably the collegiality imposed in the decision-making process, ${ }^{48}$ which was requested to be followed, notwithstanding the unavoidable preeminence of the presidents. ${ }^{49}$

The arrival of the clerk João Correia Lemos and the head treasurer of Rio de Janeiro was soon accompanied by instructions that gave them a place in the Board of Finance, sharing the same privileges of the other members: "at the same Board, they will have the seat with backrest in the same way the Ministers do, regulated by the respective antiquities". More importantly, it was

\footnotetext{
${ }^{47}$ There were complaints, without consequences. Cf. Cartas do Vice-rei, o Conde da Cunha, provedor da Fazenda, procurador da Coroa e Fazenda e Chanceler da Relação (1766). AHU, Avulsos, Rio de Janeiro, cX. 78, doc. 7.080

${ }^{48}$ In this regard, Iris Kantor detected a more general tendency, in terms of the reinforcement of the collegiate administration in the overseas governments. Íris Kantor, Esquecidos e renascidos: historiografia acadêmica Iuso-americana (1724-1759), São Paulo, Hucitec, 2003, p. 119.

${ }^{49}$ Dauril Alden, addressing in particular the case of Rio de Janeiro, during the Marquis of Lavradio government, highlighted that the Rio de Janeiro Board was, in essence, dominated by its Viceroy. Dauril Alden, Royal government in Colonial Brazil, with special reference to the administration of the Marquis of Lavradio, Viceroy, 1769-77, Los Angeles, University of California Press, 1968, p. 282. Ahead we will see that this is not always the case.
} 
General Inspector/President of the Treasury

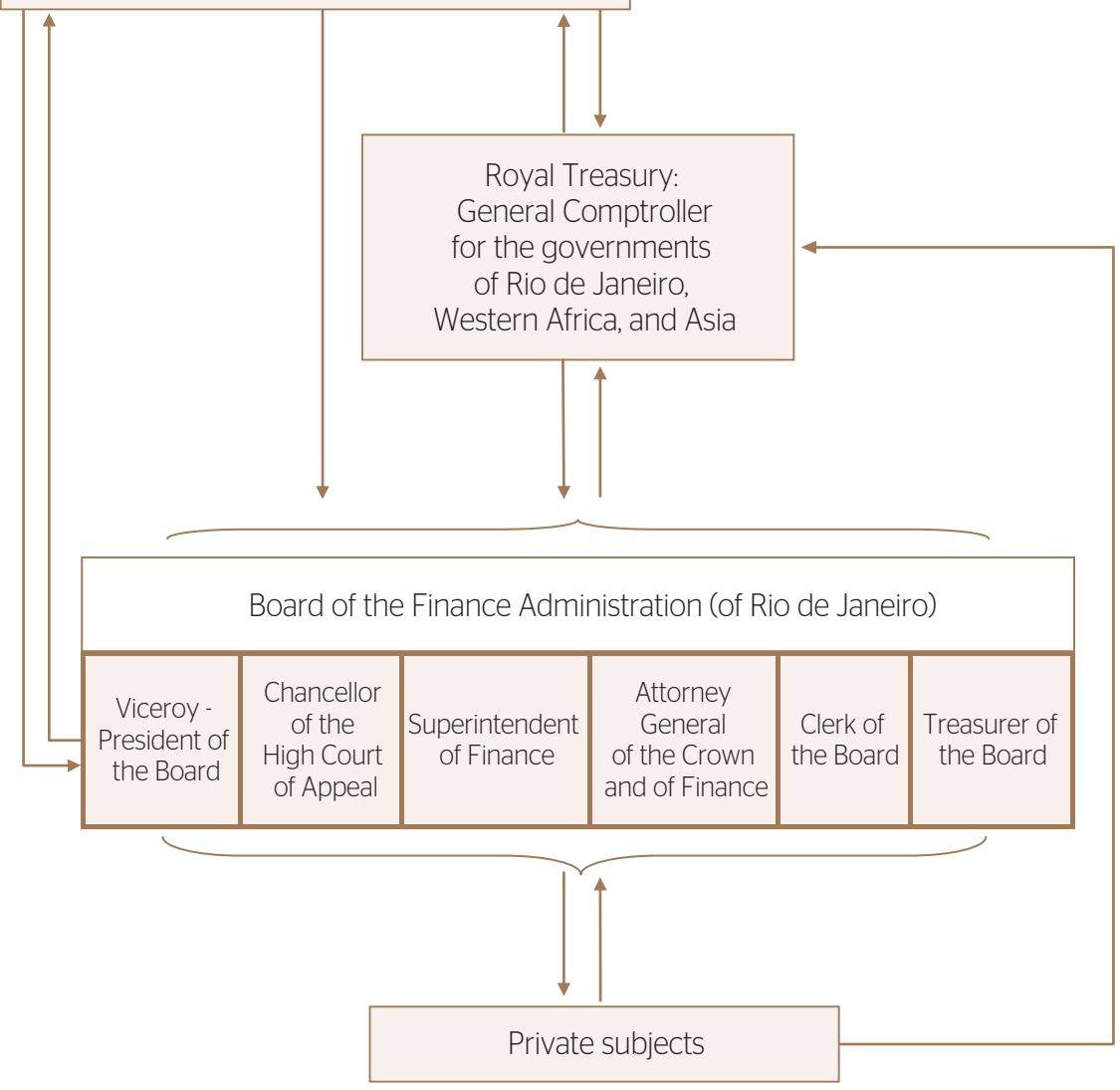

Figure 1. Base for circuit of communication Royal Treasury - Rio de Janeiro Board of Finance.

made explicit that the vote of the "truculent", but able clerk (hence the trust that Carvalho e Melo bestowed on him $^{50}$ ), and the aforementioned treasurer would be indispensible in the "issues appropriate to the said Board [...] as people versed in the formality and method of the expenditures in the Administration of the revenues, and in their collection".51 The same document that conceded formal equality to the clerk, also demanded the signature of all the members on dispatches related to expenditures. The letter expressly stated that "all papers

\footnotetext{
50 João Correia Lemos went to Rio de Janeiro in 1767 with the purpose of introducing the double-entry bookkeeping system. He would be a man of complete trust for Pombal, one of the few who, in the kingdom, had deep knowledge of the famous method invented by the Venetians. The resolution given to an argument he had with Alexandre Nunes, a prosecutor of the Crown, attests to the support he had in Lisbon: the magistrate was arrested and sent to the capital of the empire. Years later, Lavradio considered Correia Lemos to be absolutely intractable, but recognized his merits, indispensible to the proper operation of the Rio de Janeiro Board of Finance. Dauril Alden, Royal government in Colonial Brazil, with special reference to the administration of the Marquis of Lavradio, Viceroy, 1769-77, Los Angeles, University of California Press, 1968, p. 314

${ }^{51}$ Carta do Conde de Oeiras para o Conde de Azambuja, de 6 de abril de 1769. TC, ER, n. 4.103, fls. 261-263.
} 
that shall come to serve as designation for dispatch from the aforementioned treasurer will be authorized with the signature of the entire body of the Board."

It is not clear if the collegiality imposed on the modus operandi of the Boards sought to objectively reduce the natural influence of the governors/viceroys, but there is no doubt that some of them felt constrained; desolately criticizing such an order. In a certain sense, the Boards, through their functions, bolstered the metropolitan intrusion, limiting the jurisdiction of the governors when exercised individually. A case observed during the Antônio Carlos Furtado de Mendonça government, in Minas Gerais (1773-1775), shows how the establishment of a Board of Finance in that very special territory - traditionally targeted by the centripetal impulses of the Crown,$-{ }^{52}$ reflected the decrease of the jurisdiction of governors in fiscal matters.

\section{Among other central agencies, it was with the Secretaries of State that the Treasury found more obstacles in the pursuit of its political goals}

Informed by the treasurer of Minas Gerais about the behavior of Furtado de Medonça, who had suspended the new method of accounting and had determined that the "expenditures of that department be made only by way of dispatches from the governor himself [...]", the comptroller-general, in Lisbon, shared the issue with the Count of Oeiras. He noted that the "poor form and irregularity with which the Royal Finance was administrated in America gave reason for the establishment of the Boards of Finance, which His Majesty commissioned to take charge of all the administration of His Finance without the exception of a single branch". However, and still according to the comptroller-general, some governors were very dissatisfied with "the removal of the same administration from their prerogatives", and tried to maintain their prior jurisdiction. Such an act would be unacceptable and, according to Luís José de Brito's report, "quite contrary to His Majesty's orders"; therefore, the comptroller-general himself took the initiative of elaborating a provision, which he submitted to Carvalho e Melo for ratification, and which would be sent to Minas Gerais with the purpose of correcting the procedure adopted by the governor. ${ }^{53}$ On the same day, the provision was signed and dispatched, explaining that "the respective treasurer [of Minas Gerais] [should never] allow any expenditure belonging to that department that was not dispatched by the same Board". ${ }^{4}$

Modifications in the rules to fill public offices also provide a good example of a policy that restrict the governors jurisdiction in favor of the Boards. In Rio

\footnotetext{
${ }^{52}$ In this regard, see the historiographic collection of data by Júnia Ferreira Furtado, "Novas tendências da historiografia sobre Minas Gerais no período colonial", História da historiografia, n. 2, 2009, p. 116-162. ${ }^{53}$ Carta do Conde de Oeiras para o Conde de Azambuja, de 6 de abril de 1769. TC, ER, n. 4.103, fls. 261-263. ${ }^{54}$ Provisão de 13 de março de 1776. TC, ER, n. 4.073, fls. 322-323.
} 
de Janeiro, in October 1761, this important matter (directly related to patronage) was transferred to the Board of Finance, ${ }^{55}$ where the public offices began to be leased, with the exception of the ones that already belonged to someone or the ones that were perpetually rented (serventias vitalicias), which remained reserved for the monarch. ${ }^{56}$

The opposition of the governors to these measures was definitively confirmed when in August 1799, by provision of the Royal Treasury, the prerogative of the Rio de Janeiro Board was ratified. It was, therefore, with obvious dissatisfaction that D. Fernando José de Portugal wrote that the Rio de Janeiro Board of Finance was filling all public offices in the judicial and fiscal systems of the captaincy. The Viceroy could only fill the clerical offices in the High Court of Appeal of Rio de Janeiro (Tribunal da Relação), "when under his regiment and those of the Courts of Appeal of Bahia and Rio de Janeiro [he] could nominate, ${ }^{57}$ all of them (the ones from finance and justice).

\section{Conceded autonomy: signs of administrative rationalization}

The picture painted above shows the essentially centralizing nature of the reform put in practice by Carvalho e Melo. There are, however, signs that point in the opposite direction and whose meaning is important to understand. As we will see, the collegiality introduced in colonial government was supplemented by a less discussed broadening of competencies.

A formal power was delegated to the Boards, which in certain ways surpassed the framework of functions previously conceded to the peripheric administration of colonial Brazil. For example, all officials that received or spent royal revenues had to settle accounts in the respective Board. From 1760 on, the treasurers, storekeepers, collectors and other officials no longer had to travel to Lisbon. The explanation for this sudden change is given in a royal letter dated August 18, 1760. There, it was noted that the wealthiest men rejected serving in those public offices because they suffer numerous "delays" in the Contos do Reino e Casa. ${ }^{58}$

Their accounts went on to be settled in the bureau of audit (in the Board of Finance of each captancy). Subsequently those officials received a discharge letter and an extract later expedited for final ratification in Lisbon (during that year of 1760 the verification would be done in the Overseas Council and in the Secretary of State for the Navy, but, from 1761 onward, it would be up to the Royal Treasury to do such adjustments). It is important to remember that the bureau of audit was not only in charge of settling the accounts of officials of lesser consideration, which naturally dealt with small sums. The paymaster of the troops, Manuel Joaquim de Azevedo, who during the Luso-Spanish crisis

\footnotetext{
${ }^{55}$ Carta régia de 24 de outubro de 1761. Instituto Histórico e Geográfico Brasileiro (IHGB), lata 22O, doc. 1. ${ }^{56} \mathrm{BNRJ}, 09,02,026$, p. 7-12V.

57|bidem.

${ }^{58}$ Carta régia de 18 de agosto de 1760, inclusa no processo. AHU, Avulsos, Rio de Janeiro, cx. 86, doc. 16.
} 
of 1774-1777 made payments to an army that in Rio Grande do Sul alone had more than 6,300 men, ${ }^{59}$ settled his accounts with the Rio de Janeiro Board of Finance and only later was he able to return to the kingdom. ${ }^{60}$

The amount of control that the Rio de Janeiro Board of Finance began to exercise over the other local institutions is also an important testimony to the amount of flexibility granted to this same Board. We should remember that several institutions were put under the formal tutelage of the Rio de Janeiro Board of Finance: the local treasury, the bureau of audit, the Royal Mint, the Customs House, and even the Board of Frigates (a temporary court, put to work whenever a battleship arrived at harbor). In the case of the Customs House, the Board could even interfere in its staff, for example appointing "the officials that seemed more capable of better exercising the offices in the Customs House". It could even oversee and settle the salaries. ${ }^{61}$

Last, but not less important was the pivotal role assumed by the Rio de Janeiro Board of Finance in all the issues related to taxation, with the exception of the Board of Inspection (Mesa da Inspeção). Even the revenue of the Royal Mint should have been conveyed to the Board of Finance, from where they were dispatched to Lisbon. ${ }^{62}$

Like what was happening in the kingdom, with the Royal Treasury, the Boards of Finance benefitted from a tendency that favored the convergence of financial competencies in one institution. This constituted an institutional refinement, which through the delegation of certain functions, produced some kind of a decentralization of routines in imperial politics. That is, the Boards, by absorbing powers and competencies in their areas of jurisdiction, would be fulfilling the objectives of rationalization of procedures initiated by Carvalho e Melo. It was not a matter of (it probably never was) conveying all decisions to Lisbon. At least as far as the inner workings of the new financial apparatus of the empire was concerned - founded in an unmistakable relation of subordination between the American Boards of Finance and the Royal Treasury -, the initiative of Carvalho e Melo should be seen in the context of formal and rationalized delegation of powers.

The importance acquired by the Boards in the institutional spectrum of colonial governance can be confirmed by the views of D. Rodrigo de Sousa Coutinho regarding a representation of the Rio de Janeiro municipality, which tried to recover some of its old prerogatives (including the administration of State revenues). The Overseas Council was then invited to give its opinion about the long petition of that municipality, "with the exception of everything that can be said to remove the administration of the Revenues of the Boards of Finance". Such an administrative regression was incompatible with the

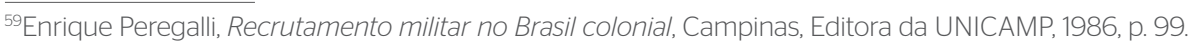
60Provisão de 19 de agosto de 1779, em que Manuel Joaquim de Azevedo recebeu a quitação geral da rainha, depois de terem sido vistas as 3 cartas de quitação passadas pela Junta da Fazenda do Rio de Janeiro. TC, ER, n. 4.055, fl. 493.

${ }^{61}$ Provisão de 26 de agosto de 1769. TC, ER, n. 4.055, fls. 114-115.

${ }^{62}$ Carta do Conde de Oeiras para o provedor da Casa da Moeda, de 13 de agosto de 1767. TC, ER, n. 4.103, fls. 143-144.
} 
well-known fiscal preoccupations of the Secretary of the State: ${ }^{63}$ in essence, the taxation should remain in the State. According to the future president of the Royal Treasury, returning the administration of the revenues to the City Councils was "contrary to the deepest founded principles of the entire Public and Economic Administration". ${ }^{4}$

\section{Unforeseen disobediences}

The structural subordination of the Boards of Finance to the inspector general and the subsequent presidents of the Royal Treasury, unquestionable as far as the legal framework was concerned, was in a certain way compensated for by the concession of a remarkable jurisdiction, even regarding matters which Lisbon had always been very sensitive about (as we have seen). It is, nevertheless, appropriate to remember that these manifestations of autonomy were in all cases previously consented and even programmed: concessions of a practical nature put forward by a minister committed to rearranging the colonial administration in a hierarchical fashion.

Such an argument is quite solid, but this did not mean that the periphery had obediently incorporated all the instructions coming from the Treasury. The path initially defined by Carvalho e Melo was far from peaceful and, regardless of the reason, the Royal Treasury was frequently incapable of imposing its will upon a distant territory that was subject to circumstances that Lisbon could not control.

Subsequently, two determining problems in the relationship maintained between the Royal Treasury and the Rio de Janeiro Board of Finance will be approached; problems that are illustrative of the particularly rough course to centralization, as a political, financial, and military decision-making process.

\section{Auctions and their location}

The first problem refers back to a sort of institutional struggle that involved the Rio de Janeiro Board and the Treasury regarding tax-farming issues, particularly the rights to auction contracts. The option was obviously not naive. Auctioning contracts not only touched on the fiscal nerve of the Crown (who stood out among other European countries for the weight attributed to the monopolies in the heading of the patrimonial revenues ${ }^{65}$ ), but also touched on the influence of the more or less subterranean networks, who were less than eager to see disappear an auctioning space which they had previously controlled.

\footnotetext{
${ }^{63}$ Regarding the fiscal approach of D. Rodrigo, see: José Luís Cardoso; Alexandre Mendes Cunha, "Discurso econômico e política colonial no Império Luso-Brasileiro (1750-1808)", Tempo, vol. 16, n. 31, 2011, p. 82-85.

${ }^{64}$ Aviso de D. Rodrigo de Sousa Coutinho ao Conselho Ultramarino, de 20 de agosto de 1799. AHU, Avulsos, Rio de Janeiro, cx. 180, doc. 36; cx. 175, doc. 86; cx. 176, doc. 45; cx. 168, doc. 12.536.

${ }^{65}$ Álvaro Ferreira da Silva, "Finanças Públicas", In: Pedro Lains; Alvaro Ferreira da Silva (orgs.), História económica de Portugal - 1700-2000: o século XVIII, vol. 1, Lisboa, ICS, 2005, p. 252.
} 
Despite its flaws, Graph 1 allows one to observe, without difficulty, the taxfarming patterns in southern Brazil in the last decades of the 18th century. As it has been previously highlighted, it seems to become clear that the majority of contracts went on to be auctioned in the colonies. It was a matter of geographical reorientation that in great part marginalized the Overseas Council. Although it was not completely banished, this Council was now far from playing the major role that D. João $\mathrm{V}$ wanted it to have. ${ }^{66}$

The transfer of decision over such delicate matters constitutes a reallocation of power, operated to the disadvantage of a central institution (the Overseas Council) for the benefit of a department of the peripheral administration (the Boards of Finance). Although the direction of this change may seem strange, it is not completely incompatible with the general posture of Pombal regarding the Overseas Council, marked by certain hostility. ${ }^{67}$ For Carvalho e Melo, the Boards of Finance offered other guarantees of loyalty, despite being at a great distance from Lisbon. The explicit dependency of an institution that he created and ran would be a decisive element in this respect.

\section{The Boards, through their functions, bolstered the metropolitan intrusion, limiting the jurisdiction of the governors when exercised individually}

The formal justification for the concession of the right to auction contracts to the Boards of Finance is mentioned in some documentation from the archive of the present-day Tribunal de Contas . Apparently, and according to the Count of Oeiras, in the middle of the 18th century, some contracts that were auction at the Overseas Council remained vacant as no interested persons appeared. ${ }^{68}$ A statement later given by the comptroller-general office points to the recurrent "disorders $[. .$.$] in the auctions that were done by the Overseas Council in the$ America contracts, being that the majority of them were done by men who were called testas de ferro (representatives of someone else), and ordinarily were unknown and lacking money". ${ }^{69}$ These two reasons had been sufficient to remove the right to auction the royal contracts from the Overseas Council,

\footnotetext{
${ }^{66}$ It is disconcerting to follow the path of the legal provisions which, during the first half of the 18th century, were sent to Brazil related to tax farming. The royal resolution of May 10, 1723 explicitly noted that "all contracts that are from my Royal Finance should be tied to this Court for three years, even the ones that are annual" (Biblioteca Nacional, Documentos Históricos, vol. 1, Rio de Janeiro, 1927, p. 92-93). On March 26, 1733, the decision over the auctioning of contracts is again transferred to Brazil (Ibidem, p. 372-373). In another resolution, stemming from the Overseas Council, dated March 2, 1736, the authority was changed, making it once again mandatory to auction contracts at the Overseas Council (Ibidem, p. 291-292).

${ }^{67}$ Most likely, the biggest display of this hostility occurred on November 22, 1765, when various governors from Portuguese America received orders not to send copies to the Overseas Council of any communication made with the Secretaries of State. Cf. Dauril Alden, Royal government in Colonial Brazil, with special reference to the administration of the Marquis of Lavradio, Viceroy, 1769-77, Los Angeles, University of California Press, 1968, p. 10.

${ }^{68}$ Provisão de 29 de agosto de 1769. TC, ER, n. 4.055, fls. 115-116.

${ }^{69}$ Exposição da Contadoria Geral, de 22 de dezembro de 1794. TC, ER, n. 4.044, fls. 142-157.
} 


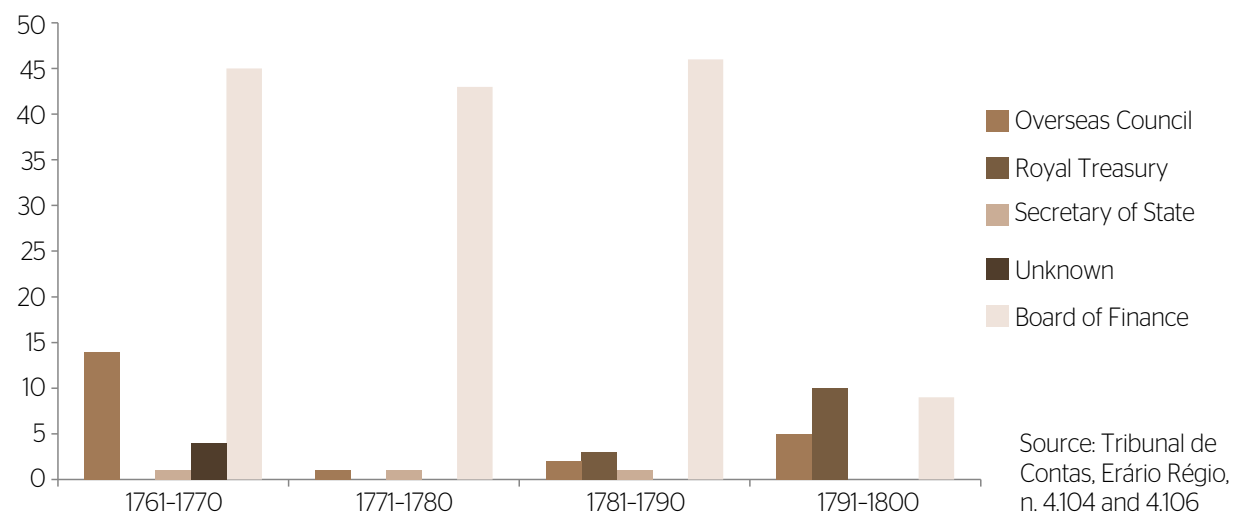

Graph 1. Auction setting of the contracts from Portuguese Southern America.

this being just one more example of the process of institutional degradation experienced by this Council.

In the same period, the Boards of Finance experienced times of great administrative vitality, auctioning contracts at their will. Naturally, any alteration to this arrangement, even if promoted by the Treasury, would not be welcomed. This was precisely what happened when in the beginning of the 1790s the president of the Royal Treasury, the viscount of Vila Nova da Cerveira, decided to take that power away from the Board of Finance. In March 23, 1790, the Rio de Janeiro Board of Finance was informed that the auctioning of several contracts should come to be done in Lisbon (although it did not go into detail in terms of the new institutional location). The legal provision mentioned: the Brandies (aguardentes) from the Kingdom and Islands, the Brandy from the Land, the transit tolls of Paraíba and Paraibuna rivers, the Tithe of Santa Catarina Island, the duties levied on slaves that went to Minas Gerais, and the Fifths of leathers from Rio Grande de São Pedro. ${ }^{70}$ Two years later, the instructions from Cerveira went a bit further, and the Rio de Janeiro Board received orders that it could only auction contracts worth less than 10 million Réis per triennium. ${ }^{71}$

Conscious of what would have been an evident restriction on their autonomy and, most importantly, to their capacity to articulate patronage networks, the members of the Rio de Janeiro Board reacted, immediately raising obstacles to the orientation received from Lisbon. On the one hand, they adopted dilatory strategies, postponing the transference of transcripts of previous contracts. In practice, this measure left the Royal Treasury in the shadows, without knowing exactly what were the traditional terms of negotiation, which left it more prone

70Provisão de 23 de março de 1790. TC, ER, n. 4.056, fl. 195.

${ }^{71}$ Provisão de 10 de março de 1792. Ibidem, fl. 257. 
to undervalue the revenues at hand. ${ }^{72}$ On the other hand, and to the dismay of Luís José de Brito and the president of the Treasury, the now Marquis of Ponte de Lima, the Rio de Janeiro Board opted to openly disobey the Treasury, continuing to auction the contracts that had been taken from them (the Slaves for Minas Gerais, the transit tolls of the Paraíba and Paraibuna rivers, and the custom stations of Viamão and Santa Vitória ${ }^{73}$ ). Lastly, the Board sought to influence the reigning prince, producing a list of inconveniences that would follow the transference of that decision to Lisbon. The method of auctioning was particularly questioned, as were the actual financial results that would probably be obtained. The defensive statement of the Treasury about the advantages gained with the new location confirms the impacts of the complaints. It also confirms the reach and the success of the resistance offered by the peripheric administration.

It is rather surprising that in the last decade of the 18th century an institutional conflict would emerge, with these kind of dimensions, between a political cornerstone of the king's power (the Royal Treasury) and a representative of the peripheric administration (the Rio de Janeiro Board), which, in addition, should have been its subordinate. Even more surprising is the fact that the former saw itself having to explain the advantages of its choices. ${ }^{74}$

\section{Financial resources for the war}

Another explicit reaction to the diligent observation of orders stemming from the Treasury is found in the administration of the financial resources for the war; an issue that Lisbon had traditionally great difficulties controlling.

With the intensification of the conflict with the Spaniards in Southern Brazil, between 1774 and 1777, and with the mobilization of the troops, the Marquis of Pombal authorized the Rio de Janeiro Boards of Finance to spend "all the money that was necessary". The sum made available was in reference to the shipments made by the Angola Board of Finance and to the revenues of the voluntary and literary subsidies. The same instructions left it quite clear that resorting to the Royal Fifths (Quintos do Ouro) was prohibited and that it should continue to be shipped to the kingdom. ${ }^{75}$

However, the many commitments arising from the military pressure lead Lavradio to use the fifths, therefore disobeying the orders of Carvalho e Melo. Although he was forgiven, Lavradio was reprehended, via the Royal Treasury, and told not to practice "similar extraction against the positive orders that had never permitted that this consignment was distributed in that captaincy for any urgent reason that arose". ${ }^{76}$

\footnotetext{
72Provisão do Visconde de Vila Nova da Cerveira, de 4 de setembro de 1793. TC, ER, n. 4.056, fl. 290.

${ }^{73}$ Provisão para o corpo da Junta, de 1 de março de 1794. TC, ER, n. 4.056, fl. 299. Provisão para o escrivão da Junta, de 28 de março de 1794. TC, ER, n. 4.056, fl. 301.

74Exposição da Contadoria Geral, de 22 de dezembro de 1794. TC, ER, n. 4.044, fls. 142-157.

${ }^{75}$ Dauril Alden, Royal government in Colonial Brazil, with special reference to the administration of the Marquis

of Lavradio, Viceroy, 1769-77, Los Angeles, University of California Press, 1968, p. 322-323.

${ }^{76}$ Provisão do Marquês de Angeja, de 24 de setembro de 1778. TC, ER, n. 4.055, fls. 410-413.
} 
It is important to highlight that such disobedience, that is, resorting to the "sacrosanct" fifths, would be repeated, for the great displeasure of Lisbon. Approximately 20 years later (1797-1798) the same Board, now presided over by Count Resende, decided to retain the fifths to support the unprecedented costs of the fleet of various battleships docked at Rio de Janeiro. In the Treasury, that choice was quickly censored. In a long statement, the comptroller-general noted that the Board of Rio de Janeiro had no valid reason to retain the fifths, especially when the kingdom found itself in the imminence of a Franco-Spanish invasion. Accusing the Board of carelessness in the administration of the "royal revenues" and of "saving [poorly] within their expenses", the comptrollergeneral seemed to recommend the imposition of restrictions to the autonomy. He noted that the

\begin{abstract}
The deliberations of the Board, along with the circumstances in which they were made, depend on a great measure, that it beware of the inconveniences that can arise in the future [...] if they carry on the expenditures that were trusted upon them and that serve as a pretext for the Board to absorb all the money that enters the coffers, like with this Royal Treasury, for the lack of shipments that should be made to it. ${ }^{77}$
\end{abstract}

The specificity of the reiterated disobedience, which prompted the comptrollergeneral to issue the above statement, is connected with the difficulty to reconcile the jurisdiction of the viceroy with the instructions of the Treasury on political and military issues. However, the same statement goes beyond that specific context when it advises a "great measure" in the sense of removing from the Boards of Finance whatever autonomy they had exercised.

Although it referred to a structural autonomy that some judged to be excessive, the resistance offered by the Rio de Janeiro Board of Finance was not always the result of an ostensive disrespect (related to jurisdiction issues). Sometimes, the circumstances made institutional cooperation impossible. In this respect, the pressure exerted by the costs associated with the maritime protection of Brazil continued to make the desired administrative solidarity between center and periphery difficult. Upholding the costs of naval fleet that the Secretary of State for the Navy sent to Brazil from 1797 onwards left the Rio de Janeiro Board and its presidents in dire straits, forcing the use of the fifths.

In September 1801, when confronted with the financial demands of the fleet commander, Donald Campbell (40 million Réis), the Count of Resende felt forced to resort to the few funds that the Board of Inspection autonomously administrated. He justified his action with the orders that Donald Campbell himself had received from the reigning prince, through the Secretary of State, which emphasized the need to provide the necessary means for the battleships patrolling the Brazilian coast.

7"Exposição do Contador Geral, de 6 de maio de 1799. TC, ER, n. 4.044, fl. 167. 
The viceroy, however, had great difficulty in persuading the deputies of the Board of Inspection, which were certainly apprehensive about the reaction of the president of the Royal Treasury. They agreed to give the money to the Board of Finance only if the Count of Resende assumed the entire responsibility of the operation, which he did. With the traditional dramatic nature of this type of correspondence, he noted "that everything that belongs to me belongs to His Royal Highness and for his service I never had and never shall have the slightest hesitation of spilling my blood until its last drop"78

The care that the viceroy put into the letter written to D. Rodrigues de Sousa Coutinho revealed the inherent discomfort of his position. As viceroy, the Count of Resende, was the primary responsible for the defense of Brazil, however, to fulfill such duty, he saw himself obliged to disrespect many of the orders that were given to him by the president of the Treasury.

\section{For Carvalho e Melo, the Boards of Finance offered other guarantees of loyalty, despite being at a great distance from Lisbon}

In Lisbon, and also writing in September 1801, D. Rodrigo de Sousa Coutinho mentioned the essential arguments presented by the Comptroller-general in 1799. In the same document where he stressed the importance "of conserving in Brazil a large fleet that could obstruct an attempt from an enemy", the president of the Royal Treasury symptomatically associated the resolution of the financial problem presented by this fleet with the fulfillment of the bureaucratic obligations of the Board of Finance. He noted, "that under these circumstances, His Royal Highness does not give bigger and more ample measures because the Board of Finance also has not sent the balance sheets of the captaincy". At the same time, he warned the Count of Resende to adopt a more judicious management of the resources, channeling them mostly to the defense. The viceroy should try to "avoid all useless expenses and make the appropriate cutbacks in everything that was not necessary for the conservation of the Army and the Navy, which assured the defense of the Captaincy" ${ }^{\prime 9}$

In the first years of the 19th century -50 years after the beginning of Sebastião de Carvalho e Melo's government and 40 years after the establishment of the Royal Treasury -, this was the picture, that in great part, determined the relationship between one of the main metropolitan political structures and one of its administrative appendices. The signs of infringement, and sometimes flat out disobedience, were very clear, and certainly incompatible with Carvalho e Melo's original plans.

\footnotetext{
${ }^{78}$ Ofício do Vice-rei para D. Rodrigo de Sousa Coutinho, de 11 de setembro de 1801. AHU, Avulsos, Rio de Janeiro, cx. 194, doc. 22; cx. 191, doc. 89; cx. 185, doc. 110.

${ }^{79}$ Ordem de D. Rodrigo de Sousa Coutinho para D. Fernando José de Portugal e Castro, de 9 de setembro de 1801. AHU, Avulsos, Rio de Janeiro, cx. 194, doc. 49.
} 


\section{Conclusion}

First and foremost, we have to emphasize the political impacts of the Royal Treasury within the Portuguese political system. The financial subordination (with administrative and political consequences) that was imposed on the general departments and councils could have been and probably should be seen as one of the most important pillars of Pombal's government. It was a clear sign of the centralizing nature of its politics that had no equivalent. Note that the General Intendancy of the Police (Intendência Geral da Polícia) - another of the main creations of this period - had its jurisdiction geographically limited.

By removing the administration of private consignments from the remaining central departments, Pombal did not only restrict their autonomy and jurisdiction, but also channeled a substantial part of the political decision over matters previously dispersed and, up to a certain point, corporately defended, toward the Treasury. Everything, or almost everything, with respect to the collection of revenue and payments was left under the vigilant eye of the Treasury. It was, therefore, a matter of converging - centralizing — what before was dispersed throughout the rest of the metropolitan political system. Furthermore, it promoted (or helped to promote) a notable concentration of power in the hands of Carvalho e Melo, who, in a significant way, became the head of the Treasury; an act that, as was previously noted, seemed to denounce that the guiding models of Pombal's political actions were not only French or Spanish. In this case, the inspiration had been essentially British. It would hardly have gone unnoticed by Carvalho e Melo, while he served as an ambassador in London, that the rising of Walpole had a lot to do with the role he played as First Lord of the Treasury (in Great Britain, directly linked to the role of Prime Minister). It was, then, a matter of replicating a formula that had proven to be successful.

This centralizing tendency was transferred onto the conquests, especially, onto Brazil, being that there was an attempt to impose an integrated and hierarchical structure between the Treasury and the Boards of Finance. The new routines of imperial government,initiated by Pombal, and which we sought to revisit, denounced a certain consonance between "the ambitions of a legislator" and "the results", at least initially. That subordination had even been reinforced by a group of other measures of a less systematized nature, as was the case of the alterations in composition of the Boards (incorporating elements totally committed to D. José I's leading minister).

The signs that apparently pointed in the opposite direction illustrate a certain institutional refinement or administrative rationalization, but which did not jeopardize the direction of Pombal's colonial policy.

This does not mean the path toward centralization had advanced without any obstacles. Much to the contrary. The tax farming problems and the administration of revenues for military purposes fostered a dynamic of opposition to the Treasury, forced to assume a defensive posture and to justify its choices. 
In reality, the difficulties faced by the central administration in the end of the 18th century, especially the institutional insubordination that was seen here, insinuate a persistence of a framework of resistance that was not entirely new, but which gained unprecedented institutional nuances.

The fact that this resistance finds itself essentially concentrated in the last decade of the 18th century makes it quite tempting to explain it in light of the end of the strong Pombaline "consulate". This is not to say his reform had been abandoned. The subsequent governments, formed during the Viradeira, ${ }^{80}$ conserved the essential ideas of the Carvalho e Melo administration, in which the Royal Treasury and the Boards of Finance system are naturally included. It is, however, legitimate to associate the lack of efficiency with the eventual sedimentation of the power of the Rio de Janeiro Board, which, over the course of time, freed itself from formal subordination; certainly to the advantage of the local elite, now more accommodated to the new inner workings of the Portuguese colonial policy. In addition, it should be mentioned that the fragility revealed by the metropolis, incapable of exercising authority in a resolute way, would have been heightened during the first years of the regency of D. João VI, a period that was marked by courtesan discord and political dispute. ${ }^{81}$

\footnotetext{
${ }^{80}$ N.T. Viradeira was a period of political change in Portugal. It was marked by the removal of Pombal from office, and according to some history marked a cut his policies.

${ }^{81}$ In this respect, see, for example, Valentim Alexandre, Sentidos do império - questão nacional e questão colonial na crise do Antigo Regime português, Porto, Afrontamento, 1993, p. 116-140, and Jorge Pedreira; Fernando Dores Costa, D. João VI: o Clemente, Lisboa, Círculo de Leitores, 2006, p. 65-83; 86-95.
} 